\title{
PENGARUH KOMPETENSI PROFESIONAL GURU TERHADAP PRESTASI BELAJAR SISWA DI SMA KRISTEN MANGKUTANA LUWU TIMUR
}

\author{
Nirma Yuliani, Sarce Rien Hana
}

\begin{abstract}
Abstrak
Tujuan dari penulisan skripsi ini untuk mengetahui apa pengaruh kompetensi profesional guru terhadap prestasi belajar siswa di SMA Kristen Mangkutana Luwu Timur. Metode yang digunakan dalam penyusunan skripsi ini adalah metode kuantitatif dengan menggunakan teknik pengumpulan data sebagai berikut: Pertama, pengumpulan data melalui riset perpustakaan, yaitu membaca buku-buku atau tulisan-tulisan yang berhubungan dengan kompetensi profesional guru terhadap prestasi belajar siswa. Kedua, memperoleh data melalui penelitian lapangan, wawancara kepada kepala sekolah dan guruguru SMA Kristen Mangkutana. Membagikan angket kepada siswa untuk mengetahui seberapa besar pengaruh kompetensi profesionl guru terhadap prestasi belajar siswa. Kesimpulan hasil penelitian menunjukkan bahwa: Pertama, kompetensi yang telah ditetapkan merupakan sebuah keharusan yang harus dimiliki oleh seorang pendidik untuk menolong tercapainya tujuan belajar. Seorang guru harus memperlengkapi diri sebelum terjun ke lapangan agar proses belajar mengajar berjalan sesuai dengan tujuan pembelajaran. Namun dari hasil penelitian penulis dapat dilihat bahwa guru yang tidak memiliki pendidikan khusus juga dapat berpengaruh positif bagi siswanya karena adanya kemauan untuk belajar. Kedua, guru harus memiliki dan menguasai kompetensi pedagogik karena seorang pendidik dituntut untuk dapat mengelola pembelajaran dan dapat mengetahui apa yang menjadi kekurangan siswa dalam proses belajar. Ketiga, kompetensi kepribadian harus dimiliki oleh seorang pendidik karena peserta didik akan menjadikan pendidik teladan untuk dapat mengubah perilakunya. Keempat, kompetensi profesional merupakan pokok dari penulisan skripsi ini. Kompetensi profesional haruslah dimiliki oleh pendidik untuk menolongnya mencapai tujuan pembelajaran.
\end{abstract}

Kata-kata Kunci: Guru, Kompetensi, Prestasi, Profesional, Siswa.

\section{Pendahuluan}

\section{Latar Belakang Masalah}

Pendidikan merupakan hal yang sangat penting bagi kehidupan manusia dan tidak dapat dipisahkan dari kehidupan manusia. Menurut Nurani Suyomukni "Pendidikan adalah proses untuk memberikan manusia berbagai macam situasi yang bertujuan memberdayakan diri." Melalui pendidikan seseorang mengalami perubahan melalui berbagai bentuk perilaku akibat dari mengalami proses belajar. Dunia pendidikan yang semakin maju saat ini tentunya menuntut prestasi seseorang dalam dunia pendidikan maka

${ }^{1}$ Nurani Suyomukti, Teori-teori Pendidikan (Yogyakarta: Ar-ruzz Media, 2015), 21. 
sangat diperlukan pembimbing yang bertanggung jawab untuk mencapai prestasi. Oleh karena tuntutan prestasi, pendidikan tidak dapat dipisahkan diri dari seorang pendidik yang profesional dalam bidangnya. Pendidik dituntut untuk memiliki kompetensi yang maksimal untuk dapat membimbing seorang siswa untuk mencapai prestasi yang juga maksimal.

Pendidikan juga merupakan hal yang dituntut oleh kitab Amsal bagi orang tua. Dalam kitab Amsal 22:6 dituliskan "Didiklah orang muda menurut jalan yang patut baginya, maka pada masa tuanya pun ia tidak akan menyimpang dari pada jalan itu." Orang tua merupakan pendidik yang Tuhan telah tetapkan pertama kali saat anak hadir di tengah dunia. Di dalam keluarga, orang tua berperan penting untuk mendidik dan membimbing anak sebelum anak tersebut masuk dalam dunia pendidikan di sekolah. Pedidikan yang didapatkan anak dalam keluarga yaitu dari orangtua akan menjadikan bekal baginya ketika anak tersebut masuk dalam dunia pendidikan di sekolah. Dalam mencapai prestasi, salah satu faktor penentu keberhasilan seorang anak adalah pendidik atau guru. Pendidik merupakan suatu penolong dan penentu seorang siswa dalam keberhasilan pendidikannya.

Seorang pendidik harus menguasai kompetensi yang telah ditetapkan dalam mengajar khususnya kompetensi profesional. Pendidik yang tidak memiliki kompetensi dalam mengajar akan menghasilkan proses belajar mengajar yang tidak maksimal. "Peran guru dalam proses mengajar merupakan ujung tombak bagi perwujudan kualitas pendidikan. Peran mulia itu merupakan bagian dari aksi nyata profesionalisme guru yang menjadi dasar pengembangan sumber daya guru."3 Guru berperan untuk mengajarkan pengetahun kepada siswanya sesuai dengan bidangnya dan tidak hanya mengetahui materi yang diajarkan, sebagai guru yang profesional harus menguasai dan dan memahami bahan ajarnya secara luas. Badrun Kartowagiran berkata dalam tulisannya:

Guru memiliki peran strategis dalam bidang pendidikan, bahkan sumber daya pendidikan lain yang memadai sering kali kurang berarti apabila tidak didukung oleh guru yang berkualitas, dan begitu juga sebaliknya. Dengan kata lain, guru merupakan ujung tombak dalam upaya peningkatan kualitas layanan dan hasil pendidikan. ${ }^{4}$

Kompetensi profesioal adalah salah satu kompetensi yang telah ditetapkan untuk dikuasai atau dimiliki oleh seorang guru dalam mengajar. Kompetensi merupakan suatu potensi atau kemampuan seorang guru dalam membimbing atau mendidik seorang anak dalam mencapai prestasi yang memuaskan. Kemampuan seorang guru dalam mendidik sangat menentukan keberhasilan siswa dalam pendidikan karena guru adalah salah satu faktor pendorong keberhasilan seorang siswa. Kemampuan seorang guru atau keprofesionalan seorang guru dapat dilihat dari kualitas siswa yang dihasilkan oleh sekolah dimana guru tersebut mengajar.

Seorang pendidik harus memperlengkapi diri dengan baik dan memiliki pengetahuan yang cukup dan siap untuk mendidik anak mencapai prestasi dalam pendidikan. Jejen Musfah mengatakan dalam tulisannya bahwa guru adalah sekumpulan orang-orang yang pintar dalam bidangnya masing-masing dan yang paling peting bagaimana cara guru tersebut dapat menularkan ilmu atau kepintarannya kepada siswanya di kelas karena guru adalah jematan bagi lahirnya anak-anak yang cerdas dan berprestasi. ${ }^{5}$

${ }^{2}$ Amsal 22:6. (TB)

${ }^{3}$ Jejen Musfah, Redesain Pendidikan Guru (Jakarta: Kencana, 2015), 47.

${ }^{4}$ Badrun Kartowagiran, "Kinerja Guru Profesional," Cakrawala Pendidikan 30, no. 3 (2011): 463, diakses 8 Maret 2019, http://staffnew.uny.ac.id/upload/130693812/penelitian/kinerja-guru-profesional-gurupasca-sertifikasi.pdf.

${ }^{5}$ Jejen Mustafah, Peningkatan Kompetensi Guru Melalui Pelatihan dan Sumber Belajar (Jakarta: Kencana, 2015), 54. 
Prestasi merupakan hasil dari pembelajaran siswa selama dibimbing oleh pendidik. Melalui prestasi dapat dilihat sejauh mana seorang siswa mengerti dan menguasai materi yang telah diberikan.

Coms menyatakan bahwa "kesuksesan tugas keguruan itu sangat terletak pada kemauan guru secara pribadi untuk berkembang". Jadi seorang guru yang sukses dan berhasil dalam pendidikan pastilah guru yang memiliki kerinduan atau kemauan secara pribadi untuk berkembang tidak hanya adanya dorongan dari luar tetapi dari pribadi guru itu sendiri. Guru perlu untuk mengembangkan pemahamannya tentang proses belajar dan harus yakin tentang potensi belajar itu sendiri demi pengembangan dirinya. ${ }^{7}$ Jadi guru harus mengerti potensi apa yang perlu dikembangkan untuk pengembangan dirinya dalam proses belajar mengajar.

Kompetensi profesional harus dimiliki oleh guru sehingga siswa merasa tertolong dalam belajar dan dalam mencapai prestasi. Namun fakta yang terjadi sekarang ini, guru juga dapat menjadi penghambat dalam pencapaian prestasi siswa dikarenakan kurang menguasai kompetensi profesional dalam mengajar. Kurangnya menguasai materi ajar, kurangnya keterampilan dalam mengajar serta kurangnya pengetahuan guru sangat mempengaruhi siswa dalam pencapaian prestasi.

Selama melaksanakan pengamatan, penulis melihat bahwa adanya kurangnya pendidikan yang dimiliki oleh guru khususnya guru Pendidikan Agama Kristen sehingga menjadikan dirinya tidak berkompeten dan mempengaruhi prestasi belajar siswa. Guru tersebut tidak memiliki pendidikan yang khusus untuk mengajar dan hal ini menjadi tolak ukur tentang pentingnya kompetensi profesional guru bagi pencapaian prestasi siswa. Berdasarkan latar belakang masalah yang telah dibahas sebelumnya, maka penulis mengambil kesimpulan untuk menulis skripsi ini yaitu dengan judul PENGARUH KOMPETENSI PROFESIONAL GURU TERHADAP PRESTASI BELAJAR SISWA DI SMA KRISTEN MANGKUTANA KABUPATEN LUWU TIMUR.

\section{Pokok Masalah}

Berdasarkan latar belakang masalah di atas, maka yang menjadi pokok masalah dalam penulisan skripsi ini:

Sejauh mana pengaruh kompetensi profesional guru terhadap prestasi belajar siswa SMA Kristen Mangkutana Luwu Timur.

\section{Tujuan Penelitian}

Adapun tujuan penulisan yang hendak dicapai sehubungan dengan penulisan skripsi ini ialah:

Mengetahui pengaruh kompetensi profesional guru terhadap prestasi belajar siswa SMA Kristen Mangkutana.

\section{Manfaat Penelitian}

Pertama, skripsi ini kiranya dapat menjadi pedoman atau pegangan bagi penulis sendiri, sebagai calon guru pendidikan agama Kristen.

\footnotetext{
${ }^{6}$ Ibid., 69.

${ }^{7}$ Ibid.
} 

pendidikan.

Kedua, kepada guru di SMA Kristen Mangkutana untuk meningkatkan kualitas

\section{Metode Penelitian}

Metode penelitian yang digunakan oleh penulis dalam penulisan skripsi ini ialah metode kuantitatif dengan penjelasan sebagai berikut: ${ }^{8}$

Pertama, pengumpulan data melalui riset perpustakaan, yaitu membaca buku-buku atau tulisan-tulisan yang berhubungan dengan kompetensi profesional guru terhadap prestasi belajar siswa.

Kedua, memperoleh data melalui penelitian lapangan, wawancara kepada kepala sekolah dan guru-guru SMA Kristen Mangkutana untuk mengetahui sejarah berdirinya SMA Kristen Mangkutana dan bagaimana perkembangan prestasi siswa. Membagikan angket kepada siswa untuk mengetahui seberapa besar pengaruh kompetensi profesionl guru terhadap prestasi belajar siswa.

\section{Batasan Penelitian}

Dalam menguraikan masalah kompetensi guru merupakan bagian yang sangat luas, maka dalam penulisan skripsi ini penulis hanya membahas pengaruh kompetensi profesional guru Pendidikan Agama Kristen terhadap prestasi belajar siswa di SMA Kristen Mangkutana Luwu Timur dan hanya mengambil 5 siswa yang masuk dalam 10 besar dari siswa yang berprestasi dan 10 dari siswa yang memiliki nilai rendah dan akan membandingkan hasil pencapaian dari tiap mata pelajaran untuk melihat sejauh mana pengaruh dari kompetensi profesional guru.

\section{Sistematika Penulisan}

Untuk memudahkan pembaca memahami skripsi ini, maka penulis menguraikan garis besar penulisan sebagai berikut:

Bab Pertama, merupakan pendahuluan yang menguraikan tentang latar belakang masalah, pokok masalah, tujuan penelitian, manfaat penelitian, metode penelitian, batasan penelitian dan sistematika penulisan.

Bab Kedua, merupakan tinjauan pustaka yang menjelaskan beberapa pokok dalam pembahasan sehubungan dengan topik penulisan skirpsi. Bagian yang pertama membahas tentang komponen kompetensi guru, pentingnya kompetensi profesional guru, kompetensi guru PAK, prestasi belajar, pengertian prestasi belajar, indikator prestasi belajar, faktorfaktor pendorong prestasi belajar, faktor-faktor penghambat prestasi belajar.

Bab Ketiga, merupakan bab yang menjelaskan gambaran umum tentang SMA Kristen Mangkutana, yaitu sejarah singkat berdirinya SMA Kristen Mangkutana, letak geografis, visi dan misi SMA Kristen Mangkutana, sarana dan prasarana SMA Kristen mangkutana, metode penelitian, populasi, sampel, teknik pengumpulan data, teknik analisis data.

Bab Keempat, membahas mengenai analisis data, pembahasan hasil penelitian dan kesimpulan analisis hasil penelitian.

Bab Kelima, kesimpulan dan saran.

\footnotetext{
${ }^{8}$ Hasmawaty, 55; Sareong dan Supartini, 29; Serli dan Wijaya, 17.
} 


\section{Kesimpulan}

Dari hasil analisis data yang telah diuraikan oleh penulis, maka penulis akan menguraikan beberapa kesimpulan mengenai pengaruh kompetensi profesional guru terhadap prestasi belajar siswa di SMA Kristen Mangkutana.

Pertama, kompetensi yang telah ditetapkan merupakan sebuah keharusan yang harus dimiliki oleh seorang pendidik untuk menolong tercapainya tujuan belajar. Seorang guru harus memperlengkapi diri sebelum terjun ke lapangan agar proses belajar mengajar berjalan sesuai dengan tujuan pembelajaran. Namun dari hasil penelitian penulis dapat dilihta bahwa guru yang tidak memiliki pendidikan khusus juga dapat berpengaruh positif bagi siswanya karena adanya kemauan untuk belajar.

Kedua, guru harus memiliki dan menguasai kompetensi pedagogik karena seorang pendidik dituntut untuk dapat mengelola pembelajaran dan dapat mengetahui apa yang menjadi kekurangan siswa dalam proses belajar. Kekurangan dalam hal ini yaitu siswa yang lambat untuk mengerti pelajaran, sulit bergaul, terlalu aktif atau juga mempunyai bakat yang tidak disadarinya.

Ketiga, kepribadian seorang guru memiliki salah satu pengaruh yang besar bagi peserta didik. Kompetensi kepribadian harus dimiliki oleh seorang pendidik karena peserta didik akan menjadikan pendidik teladan untuk dapat mengubah perilakunya. Sulit untuk dapat menghasilkan siswa yang memiliki etika jika gurunya saja tidak tahu etika itu seperti apa. Jadi, guru harus memiliki kepribadian yang siap untuk dijadikan teladan oleh siswa. Khususnya seorang guru agama Kristen, siswa sangat membutuhkan sosok guru yang bisa membawa hidup mereka serupa dengan Kristus, untuk itu guru agama mempunyai peran yang besar dalam hal ini.

Keempat, kompetensi profesional merupakan pokok dari penulisan skripsi ini. Kompetensi profesional haruslah dimiliki oleh pendidik untuk menolongnya mencapai tujuan pembelajaran. Kemampuan menguasai materi pembelajaran merupakan satu bagian yang sangat penting bahkan dikatakan yang paling utama dalam proses pembelajaran. Dengan menguasai materi, pendidik akan dengan mudah membimbing peserta didik untuk mencapai prestasi belajar. Dalam hal ini, guru PAK juga diberikan tuntutan yang sama yaitu menguasai materi yang diampunya untuk membantu siswa mengetahui tentang Tuhan.

Kelima, guru PAK merupakan seorang yang membawa siswa semakin mengerti tentang iman Kristen dan juga semakin mengenal siapa Tuhannya. Guru PAK haruslah memahami pribadi Yesus untuk dijadikannya teladan dalam melakukan tugasnya sebagai pendidik.

\section{Saran-saran}

Berdasarkan beberapa kesimpulan yang telah diuraikan di atas, maka penulis memberikan beberapa saran, yaitu:

Pertama, setiap guru seharusnya memperlengkapi diri terlebih dahulu sebelum terjun langsung dalam dunia pembelajaran. Khusunya guru agama di SMA Kristen Mangkutana, sekalipun memiliki pengalaman dan rasa mau belajar untuk bisa memperlengkapi diri dalam mendidik seharusnya juga memperlengkapi diri dengan pendidikan khusus untuk kepentingan psikologi dalam pendidikan dan juga hal-hal yang menyangkut pendidikan yang tidak dijumpai hanya karena pengalaman. 
Kedua, pihak sekolah seharsunya memperlengkapi setiap pendidik untuk dapat memiliki ke empat kompetensi yang telah ditetapkan untuk membantu siswa dalam mencapai prestasi.

Ketiga, siswa harus meningkatkan kualias dalam belajar dengan memiliki dorongan dari dalam diri untuk semakin giat belajar.

Keempat, wali atau orangtua siswa harus selalu mendukunng dan mendampingi siswa untuk mencapai prestasi belajar

Kelima, selain membimbing dalam proses memperoleh pengetahuan, guru juga harus memberikan motivasi dan dorongan bagi siswa untuk mencapai prestasi belajar.

\section{Kepustakaan}

Agung, Iskandar, Ikhya Ulumudin, Etty Sofyatiningrum. Uji Kompetensi Guru. Jakarta: Edu Pustaka, 2017.

Alkitab. Jakarta: Lembaga Alkitab Indonesia, 2006.

Bunga, Sari Selviyanti. "Pengaruh Kompetensi Sosial Guru PAK Terhadap Perkembangan Karakter Siswa di SMK 1 Kabupaten Tana Toraja." Tesis MA, STT Jaffray Makassar, 2014.

Dalyono, M. Psikologi Pendidikan. Jakarta: Rineka Cipta, 1997.

Edison, F. Thomas. 52 Metode Mengajar. Bandung: Kalam Hidup, 2017.

Gunarsa, Singgih dan Yulia Singgih Gunarsa. Psikologi Praktis Anak, Remaja, dan Keluarga. Jakarta: Libri. 2011.

Hasanah, Aan. Pengembangan Profesi Guru. Bandung: Pustaka Setia, 2012.

Hasmawaty. "Kemampuan Menyimak Anak Melalui Kegiatan Bercerita (Studi Kasus Pada Taman Penitipan Anak Athirah Makassar).” Jurnal Ilmu Teologi dan Pendidikan Agama Kristen 1, no. 1 (Juni 2020): 55-68.

https://ojs.sttjaffray.ac.id/jitpk/article/view/463/pdf_4.

Hatimah, Ihat. "Pengelolaan Pembelajaran Berbasis Potensi Lokal di PKBM." Mimbar

Pendidikan 25, no. 1 (2006): 39-45. Diakses 12 Mei 2019.

Http://File.Upi.Edu/Direktori/JURNAL/JURNAL_MIMBAR_PENDIDIKAN/MI

MBAR_NO_1_2004/Pengelolaan_Pembelajaran_Berbasis_Potensi_Lokal_Di_PK

BM.Pdf.

Ismail, Muh. Ilyas. "Kinerja dan Kompetensi Guru Dalam Pembelajaran.” Jurnal Lentera

Pendidikan 13, no. 1 (2010): 44-63. Diakses 2 Mei 2019.

http://journal.uinalauddin.ac.id/index.php/lentera_pendidikan/article/viewFile/3809/ 3480.

Kartowagiran, Badrun. “Kinerja Guru Profesional.” Cakrawala Pendidikan 30, no. 3

(2011): 463-473. Diakses 8 Maret 2019.

http://staffnew.uny.ac.id/upload/130693812/penelitian/kinerja-guru-profesional-

guru-pasca-sertifikasi.pdf.

Kristianto, Lilik Paulus. Prinsip dan Praktik Pendidikan Agama Kristen. Yogyakarta: ANDI, 2006.

Kurniasih, Imas. Sukses Uji Kompetensi Guru. Surabaya: Kata Pena, 2015.

Midarso, Hadi Yusuf. Menyemai Benih Teknologi Pendidikan. Jakarta: Kencana, 2004.

Mulyasa, E. H. Uji Kompetensi dan Penilaian Kinerja Guru. Bandung: Remaja Rosdakarya, 2013.

Standar Kompetensi dan Sertifikasi Guru. Bandung: Remaja Rosdakarya, 2013.

Musfah, Jejen. Peningkatan Kompetensi Guru. Jakarta: Kencana, 2011. . Redesain Pendidikan Guru. Jakarta: Kencana, 2015. 
Nainggolan, John. Guru Agama Kristen Sebagai Panggilan dan Profesi. Bandung: Bina Media Informasi, 2010.

Saleh, Minhayati. "Pengaruh Motivasi, Faktor Keluarga, Lingkungan Kampus dan Aktif Berorganisasi Terhadap Prestasi Akademik.” Jurnal Phenomenon 4, no. 2 (2014): 109-141. Diakses 16 Juni 2019.

http://www.journal.walisongo.ac.id/index.php/Phenomenon/article/view/122.

Sareong, Irene Priskila dan Tri Supartini. "Hubungan Komunikasi Interpersonal Guru dan Siswa Terhadap Keaktifan Belajar Siswa di SMA Kristen Pelita Kasih Makassar.” Jurnal Ilmu Teologi dan Pendidikan Agama Kristen 1, no. 1 (Juni 2020): 29-42. https://ojs.sttjaffray.ac.id/jitpk/article/view/466/pdf_2.

Serli dan Hengki Wijaya. "Metode Permainan Dalam Meningkatkan Pemahaman Firman Tuhan Pada Remaja GKII Okahapi Sumba Timur.” Jurnal Ilmu Teologi dan Pendidikan Agama Kristen 1, no. 1 (Juni 2020): 17-28. https://ojs.sttjaffray.ac.id/jitpk/article/view/459/pdf_1.

Sidjabat, S. B. Mengajar Secara Profesional. Bandung: Yayasan Kalam Hidup, 2011. . Strategi Pendidikan Kristen. Yogyakarta: Yayasan Andi, 1999.

Sugiyono. Metode Penelitian. Bandung: Alfabeta, 2018.

Sumantri, Syarif Mohamad. Strategi Pembelajaran. Jakarta: Raja Grafindo Persada, 2016. Supardi. Kinerja Guru. Jakarta: Raja Grafindo Persada, 2014.

Suprihatiningrum, Jamil. Guru Profesional. Yogjakarta: Ar-ruzz Media, 2014.

Surjana, Andyarto. "Efektivitas Pengelolaan Kelas." Jurnal Pendidikan Penabur 3, no. 02 (2004): 68-81. Diakses 2 Mei 2019. http://www.geocities.ws/dien_sib24gd/fei/068081.pdf

Surya, Mohamad. Psikologi Guru Konsep dan Aplikasinya. Bandung: Alfabeta, 2013.

Suyomukni, Nurani. Teori-teori Pendidikan. Yogyakarta: Ar-ruzz Media, 2015.

Syah, Muhibbin. Psikologi Belajar. Depok: Raja Grafindo, 2017.

Tago'a, Jusman. "Tinjauan Teologis Terhadap Budaya Pemanggilan Arwah Orang Mati Pada Suku Pamona.” Skripsi S.Th, STT Jaffray Makassar, 2010.

Wahidmurni, Mustikawan Alfin \& Ridho Ali. Evaluasi Pembelajaran. Yogyakarta: Nuha Litera, 2010.

Wijaya, Hengky (ed). Metodologi Penelitian Pendidikan Teologi. Makassar: STT Jaffray Makassar, 2017. 